\title{
Hubungan Kecemasan dengan Kualitas Hidup pada Wanita Menopause
}

\author{
Amatulqaiyum Idri Sari ${ }^{1}$, Ariadi $^{2}$, Adrial $^{3}$ \\ ${ }^{1}$ Fakultas Kedokteran Universitas Andalas, Padang \\ ${ }^{2}$ Bagian Obsteri dan Ginekologi Fakultas Kedokteran Universitas Andalas/RSUP Dr. M. Djamil Padang \\ ${ }^{3}$ Bagian Parasitologi Fakultas Kedokteran Universitas Andalas, Padang
}

\begin{abstract}
Latar Belakang. Angka harapan hidup di Sumatera Barat semakin tinggi, tingginya angka harapan hidup meningkatkan kualitas kesehatan dan jumlah wanita menopause. Gejala menopause akan mempengaruhi kualitas hidup seorang wanita, semakin berat gejala yang dialami dapat terganggunya kualitas hidup. Salah satu gejala yang dialami adalah kecemasan.

Objektif. Mengetahui hubungan kecemasan dengan kualitas hidup pada wanita menopause di Posyandu Lansia Puskesmas Nanggalo Kota Padang.
\end{abstract}

Metode. Penelitian ini merupakan penelitian analitik observasional dengan desain cross sectional pada 30 wanita menopause di Posyandu Lansia Puskesmas Nanggalo Kota Padang yang dipilih melalui purposive sampling dengan teknik wawancara menggunakan kuesioner HARS untuk mengukur kecemasan dan WHO-QOL BREF untuk mengukur kualitas hidup. Analisis data dilakukan dengan uji korelasi pearson dan uji regresi linear.

Hasil. Hasil penelitian didapatkan nilai korelasi pada setiap domain fisik, psikologis, sosial, lingkungan ( $r=-0,744,-0,781$, $0,667,-0,660)$ dengan arah korelasi negatif. Kontribusi $\left(r^{2}\right)$ kecemasan terhadap kualitas hidup setiap domain fisik, psikologis, sosial, lingkungan (55,4\%, 61\%, 44,5\%, 43,5\%) dengan persamaan regresi WHO-QOL BREF = a+(-b) HARS.

Simpulan. Ada hubungan negatif yang signifikan antara kecemasan dengan kualitas hidup.

Kata kunci : kecemasan, kualitas hidup, menopause

Background. Life expectancy in West Sumatra is getting higher, higher life expectancy increases the quality of health and the number of menopausal women. The symptoms of menopause will affect a woman's quality of life, the more severe the symptoms experienced can interfere with the quality of life. One of the symptoms experienced is anxiety.

Objective. Knowing the relationship between anxiety and quality of life in menopausal women at Elderly Posyandu Nanggalo Public Health Center Padang.

Method. This research is an observational analytic study with cross sectional design on 30 menopausal women at Elderly Posyandu Nangglo Public Health Center Padang who were selected through purposive sampling with interview techniques using the HARS questionnaire to measure anxiety and WHO-QOL BREF to measure quality of life. Data analysis was performed using Pearson correlation test and linear regression test.

Result. The results showed that the correlation value in each physical, psychological, social, environmental domain ( $r=$ $0,744,-0,781,-0,667,-0,660)$ with a negative correlation direction. Contribution $\left(r^{2}\right)$ of anxiety to the quality of life of each physical, psychological, social, environmental domain $(55.4 \%, 61 \%, 44.5 \%, 43.5 \%)$ with the WHO-QOL regression equation $B R E F=a+(-b)$ HARS.

Conclusion. There is a significant negative relationship between anxiety and quality of life.

Key words: anxiety, quality of life, menopause

\section{Apa yang sudah diketahui tentang topik ini?}

Gejala menopause akan mempengaruhi kualitas hidup seorang wanita. Semakin berat gejala yang dialami dapat terganggunya kualitas hidup.

\section{Apa yang ditambahkan pada studi ini?}

Kecemasan dapat mempengaruhi kualitas hidup pada wanita menopause dari aspek kesehatan fisik, psikologis, hubungan sosial dan lingkungan.

\section{CORRESPONDING AUTHOR}

Name: Amatulqaiyum Idri Sari

Phone: +6282170252734

E-mail: amatulqaiyumis@gmail.com

\section{ARTICLE INFORMATION}

Received: September $23^{\text {rd }}$, 2020

Revised: October $15^{\text {th }}, 2020$

Available online: October $31^{\text {st }}, 2020$ 


\section{Pendahuluan}

Angka harapan hidup perempuan di Indonesia pada tahun 2018 adalah 73,19 tahun, lebih tinggi dibandingkan angka harapan hidup laki-laki yaitu 69,3 tahun. Terjadi peningkatan angka harapan hidup pada tahun 2019 yaitu angka harapan hidup laki-laki 69,44 tahun dan perempuan 73,33 tahun. ${ }^{1}$ Di Sumatera Barat pada tahun 2018, angka harapan hidup penduduk yaitu pada usia 69,01 tahun. Kota Padang menepati urutan kedua setelah Bukittinggi, dengan angka harapan hidup pada usia 73,35 tahun. ${ }^{2}$ Semakin tingginya angka harapan hidup berarti semakin banyak pula populasi wanita yang memasuki usia menopause. Dengan meningkatnya populasi wanita menopause diharapkan kualitas hidupnya dapat meningkat.

Menopause merupakan proses alami yang dialami oleh wanita paruh baya dengan tidak terjadinya peristiwa menstruasi selama 12 bulan berturut-turut yang diakibatkan oleh penurunan fungsi dari folikel ovarium primordial secara bertahap tanpa disertai oleh penyebab lainnya. ${ }^{3}$ Gejala pada wanita menopause diantaranya kelelahan fisik dan mental (53\%), iritabilitas (48,2\%), depresi $(43,4 \%)$ dan hot flushes $(42,2 \%)$, ketidaknyamanan sendi $(47,6 \%) .{ }^{4}$ Di Amerika Latin, gejala yang paling banyak dilaporkan adalah hot flushes $(68,9 \%)$ dan gangguan tidur $(68,4 \%) .{ }^{5}$ Di Australia, menopause dikaitkan sebagian besar dengan muka memerah dan keringat malam. ${ }^{6}$ Di Nigeria, ketidaknyamanan sendi dan otot adalah gejala yang paling sering dilaporkan (59\%). ${ }^{7}$

Keluhan depresi meningkat pada masa menopause dikarenakan hormon serotonin dan noradrenalin yang tidak aktif, diakibatkan oleh peningkatan aktivitas enzim monoamine oksidase (MAO), di mana penyebab terjadinya peningkatan enzim ini dipicu oleh penurunan estrogen pada masa menopause. Steroid seks berperan dalam fungsi susunan saraf pusat, terutama terhadap perilaku, suasana hati, serta fungsi kognitif dan sensorik seseorang. Apabila terjadi penurunan sekresi steroid seks akan menimbulkan perubahan psikis dan fungsi kognitif. Kurangnya aliran darah ke otak menyebabkan sulit untuk berkonsentrasi dan mudah lupa. Penurunan hormon estrogen menimbulkan beberapa keluhan seperti mudah tersinggung, cepat marah dan berasa tertekan. Berbagai keluhan tersebut diduga dapat diakibatkan oleh penurunan hormon serotonin. ${ }^{8}$

Penelitian yang dilakukan di Puskesmas Kabanjahe Kabupaten Karo tahun 2017 pada 103 responden didapatkan hasil wanita dengan pendidikan tinggi dan pendapatan yang cukup memiliki kualitas hidup yang tinggi, lamanya masa menopause membuat sebagian besar wanita dapat lebih beradaptasi terhadap perubahan yang dialami saat menopause sehingga kualitas hidupnya lebih meningkat. Dari hasil tersebut menyatakan bahwa terdapat hubungan antara tingkat pendidikan, pekerjaan dan lamanya menopause dengan peningkatan kualitas hidup pada wanita menopause. ${ }^{9}$

Berdasarkan hasil penelitian di Puskesmas Sawah Lebar Kota Bengkulu tahun 2017 yang dilakukan pada 59 responden dengan usia 45-60 tahun menunjukkan hasil 50,8 \% responden mengalami kecemasan berat. Kecemasan dapat mengakibatkan ketengangan pada otot-otot tubuh yang akan menyebabkan dada terasa sesak, tekanan darah naik, tengkuk kram dimana keadaan ini jika terus berlanjut bisa berdampak terhadap gangguan psikologis pada wanita menopause. ${ }^{10}$

Masalah kesehatan pada wanita paruh baya menjadi perhatian utama dalam kesehatan masyarakat di seluruh dunia. Lebih dari $80 \%$ wanita mengalami gejala fisik atau psikis sebelum memasuki masa menopause dengan keluhan dan gangguan yang dirasakan dapat menyebabkan penurunan kualitas hidup. ${ }^{11}$

Kualitas hidup dijadikan sebagai hasil ukur dalam pedoman kesehatan secara keseluruhan. Oleh karena itu, sangat penting memahami bagaimana dampak menopause terhadap kualitas hidup wanita dalam sistem perawatan kesehatan. Kualitas hidup selama menopause berkaitan dengan sejauh mana seorang wanita mampu mengatasi perubahan dan gejala yang muncul. Wanita menopause mengalami berbagai perubahan yang bisa mempengaruhi kualitas hidup.12 Penurunan kualitas hidup terakait masalah kesehatan diakibatkan oleh beberapa gejala menopause tersebut. ${ }^{13}$

Gejala psikologis yang dialami pada wanita menopause adalah depresi, mudah marah, cemas, dan perubahan suasana hati. ${ }^{14}$ Kecemasan merupakan gejala suasana hati umum yang mungkin dialami oleh beberapa wanita 
menopause yang dapat mengganggu kualitas hidupnya. Kualitas hidup selama menopause berkaitan dengan sejauh mana seorang wanita mampu mengatasi perubahan dan gejala yang muncul.

Berdasarkan uraian di atas, penulis tertarik untuk melakukan penelitian dengan judul "Hubungan Kecemasan dengan Kualitas Hidup pada Wanita Menopause di Posyandu Lansia Puskesmas Nanggalo Kota Padang."

\section{Metode}

Jenis penelitian ini adalah penelitian analitik observational dengan desain penelitian cross sectional. Variabel independennya adalah kecemasan yang diukur dengan kuesioner HARS dan variabel dependennya adalah kualitas hidup yang diukur menggunakan kuesioner WHO-QOL BREF. Penelitian dilakukan pada bulan Juli 2020 di Posyandu Lansia Puskesmas Nanggalo Kota Padang.

Populasi penelitian ini adalah seluruh wanita menopause di Posyandu Lansia Puskesmas Nanggalo Kota Padang. Sampel penelitian yang dipilih adalah bagian dari populasi yang memenuhi kriteria inklusi dan tidak memiliki kriteria eksklusi. Kriteria inklusi subjek: Wanita menopause yang berumur 45-55 tahun di Posyandu Lansia Puskesmas Nanggalo Kota Padang, serta bersedia menjadi responden dalam penelitian ini. Kriteria eksklusi subjek: Wanita menopause yang mengalami gangguan psikotik, riwayat operasi ginekologi, kemoterapi dan terapi sulih hormon.

Data diperoleh dengan cara wawancara menggunakan kuesioner HARS (Hamilton Rating Scale for Anxiety) untuk menentukan derajat kecemasan dan kuesioner WHO-QOL BREF (WHO Quality of Life BREF) untuk menentukan tingkat kualitas hidup pada wanita menopause. Data dianalisis secara statistik berdasarkan variabel yang dinilai menggunakan sistem komputerisasi yaitu analisis univariat dan bivariat. Analisis univariat dilakukan untuk melihat distribusi frekuensi dari masing-masing variabel independen dan variabel dependen. Analisis bivariat dilakukan untuk menganalisis hubungan antara variabel independen dan variabel dependen. Hubungan dua variabel tersebut dianalisis dengan menggunakan kolerasi pearson dan regresi linear. Hubungan dikatakan bermakna bila $\mathrm{p}<0.05$. Penelitian ini telah lulus kaji etik dengan nomor surat: 287/KEP/FK/2020.

\section{Hasil}

Penelitian ini dilakukan terhadap 30 wanita menopause di wilayah kerja Puskesmas Seberang Padang pada bulan Juli 2020.

\section{Karakteristik Responden}

Tabel 1. Distribusi Frekuensi Karakteristik Responden

\begin{tabular}{lcc}
\hline \multicolumn{1}{c}{ Karakteristik } & $\mathrm{f}$ & $\%$ \\
\hline Usia & & \\
$45-50$ tahun & 4 & $13,3 \%$ \\
$\quad 51-55$ tahun & 26 & $86,6 \%$ \\
Tingkat pendidikan & & \\
$\quad$ SD & 2 & $6,7 \%$ \\
SMP & 5 & $16,7 \%$ \\
SMA/sederajat & 19 & $63,3 \%$ \\
S1/Diploma & 4 & $13,3 \%$ \\
Pekerjaan & & \\
$\quad$ Bekerja & 3 & $10 \%$ \\
Tidak bekerja & 27 & $90 \%$ \\
\hline
\end{tabular}

Tabel 1 menunjukkan bahwa sebagian besar responden berusia 51-55 tahun yaitu 26 orang dengan presentase $86,6 \%$ dan sisanya berusia 45 50 tahun sebanyak 4 orang dengan presentase $13,3 \%$, sebagian besar responden berpendidikan SMA/sederajat yaitu sebanyak 19 orang dengan presentase $63,3 \%$, pendidikan SD sebanyak 2 orang $(6,7 \%)$, pendidikan SMP sebanyak 5 orang (16,7\%), dan pendidikan S1/diploma sebanyak 4 orang $(13,3 \%)$, sebagian besar responden tidak bekerja/ibu rumah tangga yaitu sebanyak 27 orang dengan presentase $90 \%$ dan sisanya bekekerja sebanyak 3 orang (10\%).

\section{Distribusi Kecemasan}

Pada penelitian ini didapatkan wanita menopause lebih banyak mengalami kecemasan ringan.

Tabel 2. Distribusi Frekuensi Kecemasan

\begin{tabular}{lcc}
\hline \multicolumn{1}{c}{ Derajat Kecemasan } & Frekuensi & Presentase (\%) \\
\hline Tidak ada kecemasan & 5 & 16,7 \\
Kecemasan ringan & 18 & 60 \\
Kecemasan sedang & 7 & 23,3 \\
\hline
\end{tabular}

Tabel 2 menunjukkan sebagian besar wanita menopause mengalami kecemasan ringan, yaitu sebanyak 18 orang dengan presentase 60\%, responden dengan tidak adanya perasaan cemas sebanyak 5 orang $(16,7 \%)$, dan responden dengan 
tingkat kecemasan sedang sebanyak 7 orang $(23,3 \%)$.

\section{Distribusi Kualitas Hidup}

Pada penelitian ini didapatkan Kualitas hidup wanita menopause sedang-sangat baik.

Tabel 3. Distribusi Frekuensi Kualitas Hidup

\begin{tabular}{lcc}
\hline Tingkat Kualitas Hidup & f & \% \\
\hline Domain Fisik & & \\
$\quad$ Kualitas hidup sedang & 13 & $43,3 \%$ \\
$\quad$ Kualitas hidup baik & 17 & $56,7 \%$ \\
Domain Psikologis & & \\
$\quad$ Kualitas hidup sedang & 12 & $40 \%$ \\
$\quad$ Kualitas hidup baik & 16 & $53,3 \%$ \\
$\quad$ Kualitas hidup s. baik & 2 & $6,7 \%$ \\
Domain Sosial & & \\
$\quad$ Kualitas hidup baik & 3 & $10 \%$ \\
$\quad$ Kualitas hidup s. baik & 27 & $90 \%$ \\
Domain Lingkungan & & \\
$\quad$ Kualitas hidup baik & 3 & $10 \%$ \\
$\quad$ Kualitas hidup s.baik & 27 & $90 \%$ \\
\hline
\end{tabular}

Tabel 3 menunjukkan hasil bahwa responden memilki kualitas hidup sedang-sangat baik pada setiap domain fisik, psikologis, sosial, dan lingkungan. Responden dengan kualitas hidup sedang ada 13 orang $(48,3 \%)$ dan kualitas hidup baik ada 17 orang (56,7\%) pada domain fisik, sebanyak 12 orang $(40 \%)$ responden memiliki kualitas hidup sedang, 16 orang (53,3\%) responden memiiki kualitas hidup baik, dan sisanya 2 orang $(6,7 \%)$ dengan kualitas hidup sangat baik pada domain psikologis. Tingkat kualitas hidup responden pada domain sosial dan lingkungan menunjukkan hasil yang sama yaitu 3 orang $(10 \%)$ responden memiliki kualitas hidup baik dan 27 orang (90\%) memilki kualitas hidup sangat baik.

\section{Hubungan Kecemasan dengan Kualitas Hidup pada Wanita Menopause}

Tabel 4. Hubungan Kecemasan dengan Kualitas Hidup Berdasarkan Uji Korelasi Pearson

\begin{tabular}{lcc}
\hline \multicolumn{1}{c}{ Variabel } & $\mathbf{P}$ & $\mathbf{r}$ \\
\hline Domain Fisik & 0,000 & 0,744 \\
Domain Psikologis & 0,000 & 0,781 \\
Domain sosial & 0,000 & 0,667 \\
Domain lingkungan & 0,000 & 0,660 \\
\hline
\end{tabular}

Berdasarkan hasil uji korelasi pearson didapatkan nilai signifikansi $p>0,05$, maka dapat disimpulkan terdapat kolerasi signifikan. Nilai $r$ (korelasi) anatara -1 sampai +1 . Pada analisis data terebut terdapat nilai $r$ negatif yang berarti terdapat hubungan linear negatif sempurna. Terdapat kolerasi kuat antara kecemasan dengan kualitas hidup secara umum, domain 1 (kesehatan fisik) dan domain 2 psikologis, pada hubungan kecemasan dengan domain 3 (hubungan sosial) dan domain 4 (lingkungan) terdapat kolerasi sedang.

Tabel 5. Hubungan Kecemasan dengan Kualitas Hidup Berdasarkan Uji Regresi Linear

\begin{tabular}{lcccc}
\hline Model regresi & $\mathbf{r}^{2}$ & $\mathbf{a}$ & $\mathbf{b}$ & $\mathbf{P}$ \\
\hline Domain Fisik & 0,554 & 83,409 & $-1,234$ & 0,000 \\
Domain & 0,610 & 99,841 & $-1,959$ & 0,000 \\
Psikologis & & & & \\
Domain Sosial & 0,445 & 86,204 & $-0,717$ & 0,000 \\
$\begin{array}{l}\text { Domain } \\
\text { Lingkungan }\end{array}$ & 0,435 & 89,067 & $-0,913$ & 0,000 \\
\hline
\end{tabular}

Berdasarkan hasil uji regresi sederhana didapatkan $\mathrm{p}$ HARS (kecemasan) $<0,05$ menunjukkan adanya pengaruh signifikan antara HARS dengan WHOQOL BREF. Dari hasil uji t nilai $t_{\text {hitung }}>t_{\text {tabel, }}$ maka $\mathrm{H} 0$ ditolak. Jadi dapat disimpulkan bahwa nilai HARS (kecemasan) berpengaruh terhadap WHOQOL BREF (kualitas hidup). Nilai koefisien B negatif, artinya jika skor HARS turun maka skor WHOQOL BREF akan naik.

\section{Pembahasan}

Dari penelitian yang sudah dilakukan terhadap wanita menopause di Posyandu Lansia Puskesmas Nanggalo, didapatkan hasil mayoritas umur responden $51-55$ tahun yaitu 26 orang $(86,67 \%)$. Berdasarkan hasil penelitian ini usia menopause di Posyandu Lansia Puskesmas Nanggalo lebih tinggi dari rata-rata usia menopause nasional, yaitu pada usia 52 tahun. ${ }^{15}$ Hasil penelitian ini sesuai dengan penelitian yang dilakukan oleh Nunik Ike Yunia Sari di Puskesmas Bendo, Kediri pada tahun 2017 didapatkan 83,3\% wanita menopause berusia 51-59 tahun. ${ }^{16}$

Berdasarkan tingkat pendidikan akhir, mayoritas wanita menopuse adalah berpendidikan tamat SMA/sederajat yaitu 22 orang $(73,34 \%)$. Berdasarkan data BPS RI tahun 2019 menunjukkan presentase tingkat pendidikan perempuan yang berpendidikan SMA/sederajat sebesar 86,06\%.17 Hasil dari beberapa survei menunjukkan cukup tinggi presentase perempuan dengan tingkat pendidikan terakhir SMA/sederajat.

Berdasarkan pekerjaan, mayoritas wanita menopause tidak memiliki pekerjaan atau sebagai 
ibu rumah tangga yaitu 25 orang (83,34\%). Hasil penelitian yang dilakukan Cindy Melllinda Sari di Puskesmas Buleleng pada tahun 2019 didapatkan sebagian besar wanita menopause tidak bekerja dengan presentase $37,74 \% .{ }^{18}$

Dari hasil penelitian menggunakan kuesioner HARS didapatkan 3 derajat kecemasan yaitu tidak ada kecemasan, kecemasan ringan dan kecemasan sedang dengan menunjukkan tingkat kecemasan wanita menopause paling banyak berada pada tingkat kecemasan sedang yaitu 18 orang $(60 \%)$. Hasil penelitian Nur Hidayah dan Hilmi Alif di Dusun Ngablak Desa Kedungruken Kecamatan Benjeng Kabupaten Gresik dengan didapatkan hasil $76,3 \%$ wanita premenopause mengalami kecemasan ringan. ${ }^{19}$ Kecemasan pada menopause dihubungkan dengan perasaan khawatir terhadap suatu kondisi yang tidak pernah dialami sebelumnya. Perasaan cemas saat menopause karena terjadinya perubahan era reproduksi yang berarti terhentinya nafsu seksual dan fisik. Selama menopause, wanita mengalami berbagai perubahan biologis, sosial dan psikologis. Wanita menopause lebih sensitive terhadap tekanan psikologis, terutama kecemasan dan depresi. ${ }^{20}$

Dari hasil penelitian menggunakan kuesioner WHO-QOL BREF mayoritas wanita menopause memiliki kualitas hidup baik-sangat baik pada setiap domain fisik, psikologis, sosial dan lingkungan

Keluhan kesehatan yang dialami penduduk dapat menjadi gambaran terhadap derajat kesehatan. Masalah kualitas hidup dalam ilmu kedokteran mengacu pada definisi umum kesehatan yang diasumsikan oleh WHO sebagai keadaan mental, fisik dan kesejahteraan sosial dan bukan hanya kurangnya penyakit.

Dari hasil analisis statistik menggunakan uji korelasi pearson didapatkan nilai $(p=0,000)$, ini berarti terdapat hubungan yang signifikan $(\mathrm{p}<$ $0,05)$ dengan nilai kolerasi negatif pada domain fisik, psikologis,sosial, lingkungan (- 0,744, - 0,781, $-0,667,-0,660)$. Analisis statistik peneltian ini juga menggunakan uji regresi sederhana didapatkan nilai koefisien determinasi $\left(\mathrm{r}^{2}=\mathrm{R}=\mathrm{D}\right)$ pada nilai setiap domain yaitu domain fisik, psikologis, sosial, lingkungan $(0,554,0,610,0,445,0,435)$. Hasil analisis tersebut menunjukkan bahwa kecemasan mempengaruhi kualitas hidup dengan persentase pada domain fisik, psikologis,sosial, lingkungan $\quad(55,4 \%, 61 \%, 44,5 \%, 43,5 \%)$, sedangkan sisanya dipengaruhi oleh variabel lain. Berdasarkan hasil analisis statistik menggunakan uji kolerasi pearson dan uji regresi sederhana menunjukkan adanya hubungan yang signifikan antara kecemasan dengan kualitas hidup pada wanita menopauses, di mana semakin tinggi tingkat kecemasan yang ditunjukkan dengan meningkatnya skor HARS maka akan menurunkan kualitas hidup pada wanita menopause, ditunjukkan dengan menenurunnya skor WHOQOL BREF. Berdasarkan hasil penelitian dengan menggunakan kuesioner WHO-QOL BREF terhadapat hubungan yang kuat pada domain fisik dan psikologi, serta terdapat hubungan sedang pada domain sosial dan lingkungan terhadap kecemasan pada wanita menopause.

Pada wanita menopause terdapat berbagai gejala yang dapat menurunkan kualitas hidup. WHO-QOL BREF membagi domain kualitas hidup menjadi 4 yaitu kesehatan fisik, psikologis, sosial dan lingkungan. Kesehatan fisik mencakup aktivitas sehari-hari, ketergantungan konsumsi obat-obatan dan bantuan medis, tidak nyaman, gangguan tidur, istirahat dan aktivitas kerja. ${ }^{21}$

Gangguan tidur yang dialami tidak spesifik, biasaya terdapat keluhan kesulitan tidur, sering terbangun pada malam hari dan bangun terlalu dini di pagi hari. Menurut Study of Women's Health Across the Nation (SWAN), prevalensi gangguan tidur meningkat seiring dengan bertambahnya usia, mulai dari $16 \%$ hingga $42 \%$ pada wanita pramneopause, dari 39\% hingga 47\% pada wanita perimenopause dan dari 35\% hingga 60\% pada wanita menopause. ${ }^{22}$ Terdapat hubungan antara gangguan mood dengan gangguan tidur, hingga 90\% orang dengan gangguan mood mengalami gaangguan tidur. ${ }^{23}$ Pada wanita menopause dengan gangguan kecemasan dan gejala depresi yang lebih tinggi mengalami pola tidur yang buruk. ${ }^{24}$

Masalah psikologis gangguan mental emosional yang ditunjukkan dengan gejala depresi dan kecemasan Aspek psikologis mencakup perasaan positif, negatif, berpikir, daya ingat dan konsentrasi. ${ }^{21}$ Perubahaan kemampuan kognitif berhubungssan dengan proses penuaan, dengan penurunan daya ingat meningkat saat wanita mendekati usia menopause. ${ }^{25}$ Berdasarkan hasil Study of Women's Health Across the Nation 
(SWAN) pada 1903 wanita menopause menunjukkan hasil bahwa tingkat depresi partisipan yang dinilai oleh Studies Depression Scale (CES-D) berkolerasi dengan kecepatan pemrosesan, memori verbal dan memori kerja. ${ }^{26}$

Hubungan sosial WHOQOL BREF mencakup relasi personal, dukungan sosial, aktivitas seksual. Kecemasan berperan penting dalam penurunan aktivitas, peneltian menunjukkan kecemasan dapat menyebabkan disfungsi seksual pada wanita. 21

\section{Simpulan}

Wanita menopause di Posyandu Lansia Puskesmas Nanggalo Kota Padang paling banyak berusia 51-55 tahun, dengan pendidikan terakhir SMA/sederajat dan tidak bekerja. Derajat kecemasan pada wanita menopause di Posyandu Lansia Puskesmas Nanggalo Kota Padang paling banyak berada pada kategori ringan-sedang.

Kualitas hidup wanita menopause di Posyandu Lansia Puskesmas Nanggalo mayoritas memiliki kualitas hidup baik, adanya hubungan negatif yang signifikan antara kecemasan dengan kualitas hidup wanita menopause di Posyandu Lansia Puskesmas Nanggalo Kota Padang di mana jika kecemasan meningkat maka akan menurunkan kualitas hidup wanita menopause secara umum yang berhubungan dengan kesehatan fisik, psikologis, hubungan sosial dan lingkungan.

\section{Ucapan Terima Kasih}

Terima kasih penulis sampaikan kepada semua instansi yang telah membantu penyelesaian penilitian ini terutama Dinas Kesehatan Kota Padang, Provinsi Sumatera Barat.

\section{Daftar Pustaka}

1. Badan Pusat Statistik. Angka harapan hidup laki-laki dan perempuan di Indonesia. https://www.bps.go.id/QuickMap?id=0000000000 . Diakses April 2019.

2 Badan Pusat Statistik Provinsi Sumatera Barat. Angka harapan hidup di Sumatera Barat tahun2018.https://sumbar.bps.go.id/dynamictable/ 2016/10/18/32/angka-harapan-hidup-pendudukprovinsi-sumatera-barat-2010-2016-metode-baru.html. Diakses Desember 2019.

3. World Health Organization, Research on the Menopause in the 1990s: Report ofa WHO Scientific Group,

1996,http://apps.who.int/iris/handle/10665/4184 1. Diakses Desember 2019.

4. Lenora J, Alwis G, Lekamwasam S, Prevalence and Severity of Menopausal Symptoms and the Quality of
Life in Middle-aged Women: A study from Sri Lanka. Nursing Research and Practice. Volume 2019.

5. Chedraui P, Miguel GS, Avila C. Quality of life impairment during female menopausal transition is related to personal and partner factors.2009.Feb;25(2):130-

5.doi:10.1080/09513590802617770.

6. Gisolf JB, Begum N, Dobson AJ. Symptoms reported by women in midlife : menopausal transition or aging ? Sep-Oct 2009;16(5):1021-9.doi: 10.1097/gme.0b013e3181a8c49f.

7. Olaolorun FM, Lawoyin TO. Experience of menopausal symptoms by women in an urban community in Ibadan Nigeria. Menopause.2009;16(4):822-30. doi: 10.1097/gme.0b013e318198d6e7.

8. Baziad A. Menopause dan Andropause. Jakarta :Yayasan Bina Pustaka Sarwono Prawirohardjo, 2003.p1-12.

9. Tarigan I, Sinuhaji LN Br, Sembiring M. Hubungan pendidikan, paritas, pekerjaan dan lama menopause dengan kualitas hidup perempuan di Puskesmas Kabanjahe Kabupaten Karo. Jurnal Mutiara Ners : Januari 2019, Vol. 2 No.1.

10. Puspita L. Marlina R. Hubungan tingkat kecemasan, status gizi dan dukungan keluarga terhadap perilaku wanita menopause. Jurnal of Nursing and Public Health : April 2019. Volume 7 No. 1.

11. Poomalar GK, Arounassalame B. The quality of life during and after menopause among rural women; 2013. Journal of Clinical and Diagnostic Research, 7(1): 135-139. doi: 10.7860/JCDR/2012/4910.2688.

12 Ceylan B, Ozerdogan N. Factors affecting age of onset of menopause and determination of quality of life in menopause; 2015. Journal Turkish Society Obstetrics Gynecology, 12(1): 43-49. doi: 10.4274/tjod.79836.

13. Marlatt Kl, Beyl RA, Redman LM (2018). A qualitative assessment of health behaviors and experiences during menopause : A cross-sectional, observational study. Maturitas, 116: 36-42. doi: 10.1016/j.maturitas.2018.07.014.

14. Ahlawat P, Singh MM, Garg S, Mala YM. Prevalence of Depression and its Association with Sociodemographic Factors in Postmenopausal Women in an Urban Resettlement Colony of Delhi. J Midlife Health. 2019 Jan-Mar; 10(1): 3336.doi: 10.4103/jmh.JMH_66_18.

15. Kementrian kesehatan direktorat promosi kesehatan dan pemberdayaan masyarakat. Promkes.kemkes.go.id. Diakses 12 Agustus 2020.

16. Sari NIY. Adriani RB. Mudigdo A. Effect of menopause duration and biopsychosocial factors on quality of life of women in Kediri District, East Java : 2017. e-ISSN: 2549-0257.

17. Badan Pusat Statistik 2019. Angka partisipasi kasar (APK) SMA/SMK/MA/sederajat menurut jenis kelamin, 2015-2019. https://www.bps.go.id/dynamictable/2018/06/05/ 1432/angka-partisipasi-kasar-apk-sma-smk-masederajat-menurut-jenis-kelamin-2015---2019.html. Diakses Juli 2020.

18. Sari CM. Rismayanti IDA. Erawan DPA. Supartin K. Hubungan indeks massa tubuh dengan kadar asam urat pada wanita post menopause di wilayah kerja Puskesmas Buleleng III : Maret 2019. Jurnal Kesehatan MIDWINERSLION Vol. 4, No. 1.

19. Hidaayah $\mathrm{N}$, Alif $\mathrm{H}$. Hubungan tingkat kecemasan 
dengan terjadinya insomnia pada wanita premenopause di Dusun Ngablak Desa Kedungrukem Kecematan Benjeng Kabupaten Gresik. Jurnal Kesehatan Ilmiah, Vol 9, No. 1, Februari 2016, hal 69-76.

20. Feldman P. Papalia D. Menyelami perkembangan manusia (experience human development). Jakarta: Salemba Humanika 2014.

21. WHOQOL BREF 1996. https://www.who.int/mental_health/media/en/76. pdf. Diakses Juli 2020.

22 Kravitz HM, Joffe H. Sleep during the perimenopause: a SWAN story. Obstet Gynecol Clin North Am. 2011 Sep; 38(3):567-86.

23. Tsuno N, Bbesset A, Ritchie K. Sleep and depression. J. Clin Psychiatry; 2005; 66(10):1254-1269.

24. Moreno FC, Figueroa VN, Malacara JM. Relationship of sleep alterations with perimenopausal and postmenopausal symptoms. Menopause; 2014; (9): 1017-1022.

25. Weber M, Mapstone M. Memory complaints and memory performance in the menopausal transition. Menopause; 2009; 16: 694-700.

26. Carleton RN, Thibodeau MA, Taela MJ, et al. The center for epidemiologic studies depression scale: a review with a theoretical and empirical examination of item content and factor structure. PLoS One; 2013; 8: e58067. 